\title{
Eating at the edges: the feeding mode and the individual-resource networks of a characid fish in the periphyton
}

\author{
Comendo pelas bordas: o modo de alimentação e a rede de interação de recursos \\ individuais de um peixe caracídeo sobre o perifíton
}

\section{Ubirajara Lima Fernandes ${ }^{1}$ (D), Grasiela Casas ${ }^{2,3}$ (D), Taise Miranda Lopes ${ }^{1}$ (D), Leandra Palheta ${ }^{2}$ (D), Liliana Rodrigues $^{1,4}$ (D) and Bárbara Dunck ${ }^{2 *}$ (D)}

\begin{abstract}
${ }^{1}$ Programa de Pós-graduação em Ecologia de Ambientes Aquáticos Continentais - PEA, Universidade Estadual de Maringá - UEM, Avenida Colombo, 5790, Bloco G-90, sala 08, CEP 87020-900, Maringá, PR, Brasil

${ }^{2}$ Programa de Pós-graduação em Ecologia, Instituto de Ciências Biológicas, Universidade Federal do Pará - UFPA, Rua Augusto Correa, 01, bairro Guamá, CEP 66075-110, Belém, PA, Brasil

${ }^{3}$ Programa de Pós-graduação em Biodiversidade e Evolução, Campus de Pesquisa Museu Paraense Emílio Goeldi, Avenida Perimetral, No 1901, Bairro Terra Firme, CEP 6607-530, Belém, PA, Brasil

${ }^{4}$ Núcleo de Pesquisas em Limnologia, Ictiologia e Aquicultura - Nupélia, Universidade Estadual de Maringá - UEM, Avenida Colombo, 5790, Bloco G-90, sala 08, CEP 87020-900, Maringá, PR, Brasil *e-mail: dunck.barbara@gmail.com
\end{abstract}

Cite as: Fernandes, U.L. et al. Eating at the edges: the feeding mode and the individual-resource networks of a characid fish in the periphyton. Acta Limnologica Brasiliensia, 2020, vol. 32, e303.

\begin{abstract}
Aim: We evaluated the predation interactions between Moenkhausia sanctaefilomenae and periphytic algae, in the presence or absence of an intermediate consumer (zooplankton). We tested the following hypotheses using a microcosms experiment: 1) fish consume zooplankton when available, therefore reducing algae consumption and increasing algal biomass; 2) fish consume the same algal species in the presence or absence of zooplankton; 3) species from the low-profile of the periphytic algal matrix are less consumed; 4) there is no difference in the nestedness of the networks between treatments, but the network in the treatment with zooplankton is modular; 5) the treatment with zooplankton shows higher interaction diversity, evenness and specialization degree. Methods: The microcosms were separated in three treatments, control (no herbivores), T1 with periphytic algae and fish, and T2 with periphytic algae, fish and zooplankton. After seven days of experiment, the stomach contents were analyzed and quantified according to the algal profiles of the periphytic matrix. We also used the individual-resource network to investigate the differences in the individuals' diet preferences between treatments. Results: The fish diet did not differ between food webs with zooplankton presence or absence. They fed more on the algal medium profile, which also predominated in the control. The main food items were the diatoms Ulnaria ulna and Achnanthidium minutissimum. The interaction network results showed that the two treatments presented network modularity, and T2 (with zooplankton) presented nested network, in addition to showing greater interaction diversity and evenness, and less specialization of interactions. Conclusions: Moenkhausia sanctaefilomenae can take advantage of a more abundant resource, and the presence or not of zooplankton did not alter the herbivory interaction. Considering the individualresource network patterns, individuals of fish showed differences in how they share resources between treatments, with presence of opportunistic and selective individuals, and distinct distribution and diversity of interactions in the presence of zooplankton.
\end{abstract}

Keywords: complex networks; herbivory; trophic interactions; floodplain; subtropical. 
Resumo: Objetivo: Nós avaliamos as interações de predação entre Moenkhausia sanctaeflomenae e algas perifíticas, na presença ou não de um consumidor intermediário (zooplâncton). Nós testamos as seguintes hipóteses através de um experimento em microcosmos: 1) peixes consomem zooplâncton quando disponível, reduzindo o consumo de algas e aumentando a biomassa algal; 2) peixes consomem as mesmas espécies de algas na presença ou ausência de zooplâncton; 3) espécies do perfil inferior da matriz perifítica são menos consumidas; 4) não há diferença no aninhamento das redes entre os tratamentos, mas a rede no tratamento com zooplâncton é modular; 5) o tratamento com zooplâncton apresenta maior diversidade, equitabilidade e especialização das interaçôes. Métodos: Os microcosmos foram separados em três tratamentos, controle (ausência de herbívoros), T1 com algas perifíticas e peixes, e T2 com algas perifíticas, peixes e zooplâncton. Após sete dias de experimento, os conteúdos dos estômagos foram analisados e classificados de acordo com o perfil ocupado pelas algas na matriz perifítica. Nós também usamos análises de rede em nível de indivíduo para investigar as diferenças na dieta dos peixes entre tratamentos. Resultados: A dieta dos peixes não diferiu entre as redes alimentares na presença ou ausência de zooplâncton. Eles se alimentaram mais de algas do perfil médio, que também predominaram no controle. Os principais itens alimentares foram as diatomáceas Ulnaria ulna e Achnanthidium minutissimum. Os resultados das redes de interação demonstraram que os dois tratamentos apresentaram modularidade de rede, e que T2 apresentou rede aninhada, além de maior equitabilidade e diversidade de interaçôes, e menor especialização de interaçôes. Conclusóes: Moenkhausia sanctaefilomenae pode aproveitar um recurso mais abundante e a presença ou não de zooplâncton náo alterou a interação de herbivoria. Considerando padróes individuais de rede, os indivíduos de peixes demonstraram diferenças entre os tratamentos no modo em que compartilham recursos, com a presença de indivíduos generalistas e especialistas e distinta distribuição e diversidade de interaçóes na presença de zooplâncton.

Palavras-chave: redes complexas; herbivoria; interaçôes tróficas; planície de inundação; subtropical.

\section{Introduction}

Trophic relationships dictate the flow of energy and cycling of nutrients in natural ecosystems (Duffy, 2002; Thompson et al., 2012). The character of the interaction between consumers and resource, whether it produces top-down or bottom-up trophic effects (Liess \& Hillebrand, 2004; Schmitz, 2008), can thus affect ecosystem processes, such as primary production, organic matter decomposition, and nutrient cycling. Furthermore, consumers can alter resource community structure and diversity (Crawley, 1989). The understanding of how consumers affect communities and ecosystems is challenging due to the diversity of both consumers and resources and the multitude of possible interactions between them.

Given the vast variety and complexity of plants, herbivores, and their interactions, a general understanding of how herbivores affect communities and ecosystems is challenging (Huntly, 1991). Network analyses can help in disentangle some of these complex relationships. The study of interaction network through network theory and its complexity has grown extraordinarily in recent decades (Strogatz, 2001; Lewinsohn et al., 2006a, b). However, individuals in a population can use resources differently, varying the degree of diet overlap (Bolnick et al., 2002), and most studies have not addressed this variation. The network approach can be used to describe the individuals' diet overlap, and the number of network studies at the population level, called individual-resource network, has recently increased (Araújo et al., 2008, 2010; Pires et al., 2011; Camargo et al., 2019). The metrics used in the study of interaction networks, which are diverse, include metrics that describe the structure of networks. The structural patterns formed by individual-resource networks, such as nestedness and modularity, can reveal distinct aspects of how individuals share resources. In individual-resource networks, a nested pattern is when the diet of selective individuals is a subset of the diet of less selective individuals (Araújo et al., 2010; Pires et al., 2011). Modularity means that there is a subset of individuals that share similar diets, having specialized in distinct sets of resources (nodes), interacting more frequently with each other than with other groups of individuals (modules) (Tinker et al., 2012). Previous studies have showed that nestedness and modularity can vary in individual-resource networks according to the availability of resources, different types of food resources preferences, habitat structure and feeding strata habits (Araújo et al., 2008; Camargo et al., 2019; Santamaría et al., 2020). Other metrics used in the study of interaction networks include the network diversity, such as interaction diversity, interaction evenness and specialization. Specialization, as it is related with resources complementarity, can be indicative of 
niche differentiation (Blüthgen, 2010), causing a decrease in individuals, competition and an increase in coexistence.

Among the main primary producers of freshwater environments, periphytic algae configure an important source of food for different types of consumers, taxonomically distinct, that can feed differently and in many layers of the periphytic biofilm, as snails, caddisfly larvae, mayfly larvae, chironomid larvae, fish or tadpoles (Power et al., 1988; Steinman, 1996; Moulton, 2006; NeuryOrmanni et al., 2016). Herbivores have direct (by consumption) and indirect effects (excretion of nutrients, removal of senescent cells, or increased uptake of nutrients by the remaining cells) in structuring periphytic algae (Hillebrand \& Cardinale, 2004; Liess \& Hillebrand, 2004; Hillebrand, 2009). Their effects can lead to positive (growth and reproduction) or negative (death or loss) responses of periphytic algae (Dunck et al., 2018). One indirect positive effect is known as keystone predation in which consumption can lead to the further development of uneaten algal species (Hillebrand et al., 2000; Duffy, 2002), after excluding others by consumer ingestion (Kupferberg, 1997), and then leads to an increase of algal biomass of some or all periphytic algal species (Liess \& Hillebrand, 2004). But, as one direct negative effect, this consumption can lead to a reduction in biomass and loss of algal diversity of the periphytic biofilm (Loman, 2001; Yang \& Dudgeon, 2010; Connelly et al., 2014).

Aquatic herbivores have different mouth parts and feeding habits that will affect periphyton community composition differently, depending on whether they are mainly scrapers, gatherers and shredders (Lamberti et al., 1987; Steinman, 1996). Considering that periphytic algae can present contrasting physiognomies in the biofilm, due to their distinct life forms and adherence to substrates, distinct species occupy distinct layers within the biofilm. Algae can occur close to the substrate (lowprofile), as well as at more intermediate (medium) or more external layers in the biofilm (high-profile) (Steinman, 1996; Passy, 2007). For this reason, the individual ways in which herbivores feed can also alter the structure and physiognomy of algal communities (Steinman, 1996; Yang \& Dudgeon, 2010; Dunck et al., 2018).

In freshwater lentic ecosystems, fish and zooplankton (mainly scraper cladocerans) are important herbivores of periphytic algal communities (Feminella \& Hawkins, 1995;
Steinman, 1996). Both have distinct behavior and feeding modes, and can change periphytic algal communities, both in terms of taxonomic and functional diversity, since algal growth strategies and size can increase or reduce consumption (Nicola et al., 1990; Feminella \& Hawkins, 1995; Steinman, 1996; Hillebrand et al., 2000). Moenkhausia sanctaeflomenae (Steindachner, 1907), a Characidae popularly known as Red-eye tetra, have a great feeding plasticity, consuming the most abundant resources in the environment (Casatti, 2002; Alanis et al., 2009; Crippa et al., 2009; Santana-Porto \& Andrian, 2009; Santos et al., 2009; Tófoli et al., 2010; Dias et al., 2017). Studies have shown that $M$. sanctaefilomenae is a trophic opportunist, and feeds on the more abundant resource in different environments (Silva \& Hahn, 2009). In a reservoir, $M$. sanctaefilomenae showed a tendency towards insectivory upstream the reservoir, zooplanktivory (in the reservoir), and tendency of herbivory downstream the reservoir (Silva \& Hahn, 2009). In distinct lakes from upper Paraná River floodplain, $M$. sanctaeflomenae used zooplankton as a food resource, with cladocerans and microcrustaceans as the main resources in some of them (Dias et al., 2017; Carniatto et al., 2019).

In the upper Paraná River floodplain, to which $M$. sanctaefilomenae is native and omnivorous, it used aquatic plants and microcrustaceans as food resources (Dias et al., 2017). Among secondary resources, the consumption of aquatic plants is greater than that of microcrustaceans in a natural environment (Dias et al., 2017). The consumption of aquatic plants may come from the ingestion of aquatic macrophytes in foraging by other food resources, such as very attached periphytic algae. Thus, the presence of periphytic algae and zooplankton in the diet indicates that $M$. sanctaeflomenae can select zooplankton or periphytic algae in competitive situations for resources, if they are more available (Carniatto et al., 2019).

Here, we evaluated the predation interactions between $M$. sanctaefilomenae and periphytic algae, in the presence or not of an intermediate consumer (zooplankton), by monitoring the fish diet. For this, we conducted an experiment in which fish individuals were subjected to treatments with and without zooplankton, and inserted in aquariums with periphyton as available food. A previous study showed that periphyton as food source was effective for fish and zooplankton, and algal densities decreased at the end of the experiment (Dunck et al., 2018). We evaluated the abundance 
and composition of periphytic algae consumed by fish with and without the presence of potential intermediate consumers (zooplankton). We also used individual-resource network tools to assess differences in structure (nestedness and modularity), algal species and fish individual degree (the number of interactions that a species establishes with others), interaction diversity, interaction evenness and specialization degree between prey species and predator individuals among the treatments.

We tested the following hypotheses: 1) fish consume zooplankton when available, therefore reducing algae consumption and increasing algal biomass; 2) fish consume the same algal species with or without the presence of zooplankton; 3) species from the low-profile of the periphytic algal matrix are less consumed; 4) there is no difference in the nestedness of the networks between treatments, but the network in the treatment with zooplankton is modular; 5) the treatment with zooplankton shows higher interaction diversity, evenness and specialization degree than the treatment without zooplankton. We thus predicted that the consumption of periphytic algae by $M$. sanctaeflomenae would be low in the presence of zooplankton, which is easier to be captured in the water column (Santos et al., 2009; Silva \& Hahn, 2009; Dias et al., 2017; Carniatto et al., 2019) and that the catching behavior of this fish (Casatti et al., 2002) would favor feeding on algal species present at more external profiles of the periphytic biofilm. We further expected that the presence of an intermediate consumer would lead to a greater niche differentiation and less competition among fish individuals resulting in higher specialization of the network, as well as higher distribution (higher evenness) and diversity of interactions than in the absence of an intermediate consumer. Finally, we expected that an increase in the diversity of food resources, considering zooplankton as another food item in addition to algae, would lead to an increase in diet segregation into different groups, generating a modular pattern as a possible mechanism for avoiding intraspecific competition (Camargo et al., 2019); and that both networks between treatments would be nested since individual-resource networks tend to be nested more commonly than modular (Pires et al., 2011).

\section{Material and Methods}

\subsection{Sampling in the lake}

To perform the experiment, we first carried out samplings and prepared the microcosms. The samplings were done in the lake "Lagoa das Garças" in the upper Paraná river floodplain (22 54'30.3"S, 5338'24.3"W; 2244'50.76"S, $\left.53^{\circ} 15^{\prime} 11.16^{\prime \prime W}\right)$. We used $6 \times 3 \mathrm{~cm}^{2}$ inert glass slides placed in the lake for 28 days to allow for algal colonization. Approximately 300 slides organized by drawers were attached to three wooden supports, near banks of the aquatic macrophyte Eichhornia azurea Kunth. This procedure was done to favor the same pool of propagules in colonization. The mean depth of the slides during the colonization ranged from 10 to $30 \mathrm{~cm}$. After that period of colonization (Rodrigues \& Bicudo, 2001), the slides were removed from the lake, put in a cooler with ice, to be later placed in the microcosms in the same day (Figure 1).
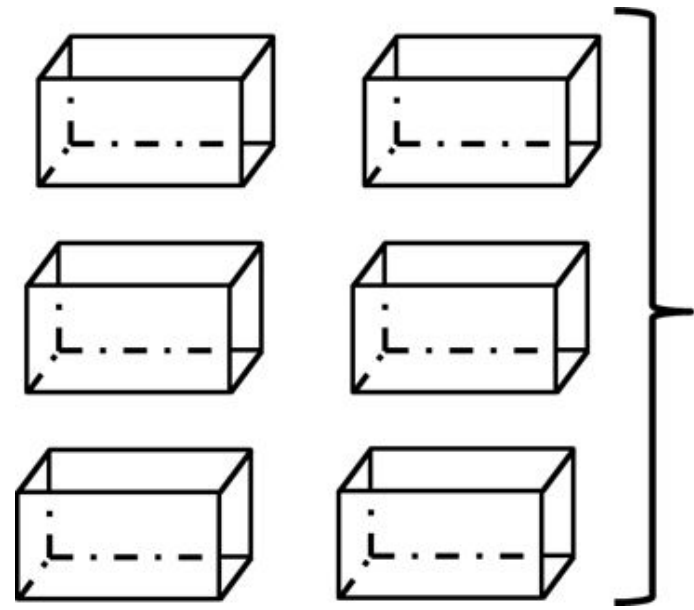

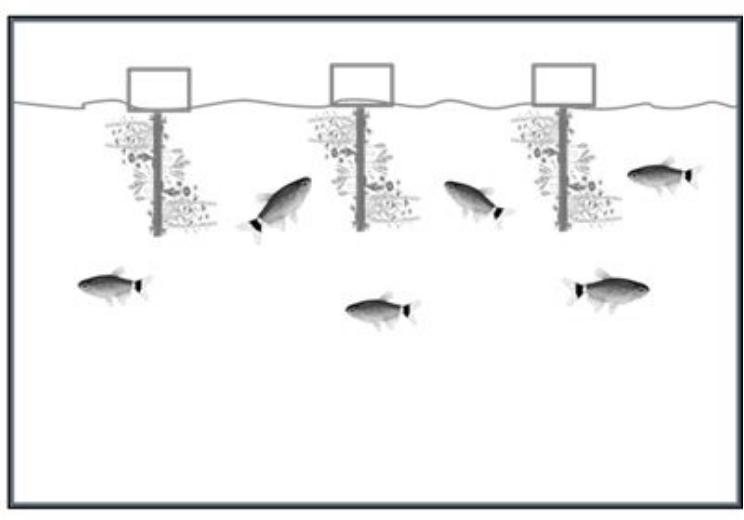

Figure 1. Schematic representation of aquariums with the colonized slides attached to a styrofoam support and individuals of the fish Moenkhausia sanctaefilomenae. Scales do not match actual sizes. In each aquarium, seven fish were included and 20 colonized glass slides were attached to a styrofoam support and inserted perpendicularly to the water surface. 
We sampled -100 individuals of the native fish species $M$. sanctaefilomenae using acrylic passive traps (plexiglass-type minnow traps, Dibble \& Pelicice, 2010), and kept in tanks for a week with air compressors. During the acclimatization, the fishes were fed with commercial fish feed, and before the beginning of the experiment, they were kept for 24 hours without food. We took seven random fish (including males and females), with mean length of $29.6 \mathrm{~cm}(\min =21 \mathrm{~cm}$ and $\max =39 \mathrm{~cm})$, to be added per aquarium to start the experiment. These fish densities are similar to those found in "Lagoa das Garças" (Dias et al., 2017). With the progress of the experiment, any lost fish individuals were replaced with new individuals in the same initial conditions (acclimatized and fed).

We prepared $2 \mathrm{~L}$ of zooplankton (Rotifera, Cladocera and Copepoda) mix sample from the lake. Zooplankton were sampled by vertical dragging with a plankton net of 45 and 68 micrometers, in the subsurface along the littoral zone of the lake, in the same locations where our algae sampling (see above) was carried out.

\subsection{Experimental design}

The experiment was carried out using $40 \mathrm{~L}$ aquaria in open field at the advanced field study base of the 'Universidade Estadual de Maringá. The experimental design of microcosms was organized in three treatments, each one with three aquarium replicates: C- control (no herbivores, only periphytic algae), T1- treatments with periphytic algae and fish, and T2- treatments with periphytic algae, fish and zooplankton.

Microcosms were filled with $35 \mathrm{~L}$ of filtered ( $45 \mu \mathrm{m}$ mesh size) water from the Paraná River. To control the limnological variables of the water we maintained an air compressor in all microcosms during the experiment, we covered each microcosm with transparent tulle to prevent entry of insects that could serve as food for fish, and we created shade to control the temperature of the microcosms. The average water temperature was $31.7^{\circ} \mathrm{C}$ (ranged from 27.5 to $36^{\circ} \mathrm{C}$ ).

In each aquarium we placed 20 glass slides colonized by algae and attached to a styrofoam support and inserted perpendicularly to the water surface, which allowed the entire area of the slide to be used by herbivores. All glass slides were equally submerged in the water. In control aquariums, we added only the 20 colonized glass slides. In T1 (treatments with periphytic algae and fish), in addition to the glass slides, we added seven individuals of $M$. sanctaefilomenae. In T2 (treatments with periphytic algae, fish and zooplankton) we added 20 algae-colonized glass slides, seven individual fish, and $350 \mathrm{~mL}$ of the homogenized zooplankton sample to each aquarium. We used the whole zooplankton community and did not selected for specific organisms, species or groups. To replace fish losses during the experiment, new individuals were inserted when necessary, always obeying the density of seven fish per aquarium.

The zooplankton abundances in each microcosm were quantified according to Bottrell et al. (1976), at the beginning (T1 - mean 85.7 ind. $\mathrm{L}^{-1} \pm \mathrm{SD}$ 61.8; T2 - mean 139.0 ind. $\mathrm{L}^{-1} \pm$ SD 116.9$)$ and end $\left(\mathrm{T} 1\right.$ - mean 1,257.1 ind. $\mathrm{L}^{-1} \pm$ SD 505.4; $\mathrm{T} 2$ - mean $1,985.8$ ind. $\left.\mathrm{L}^{-1} \pm \mathrm{SD} 1,783.5\right)$ of the experiment (for details see Dunck et al., 2018).

After 7 days of experiment, all fish were removed and preserved for further analyses. In addition to the 42 fish inserted at the beginning of the experiment, 33 more fish were inserted, totaling 75 fish collected at the end of the experiment ( 43 in T1 and 32 in T2). Dead fish were also analyzed. They were placed in bottles and fixed with $10 \%$ formaldehyde, and after being preserved for 4 days, they were transferred to a container with $70 \%$ alcohol. The stomachs were dissected, labeled and kept in $70 \%$ alcohol. We analyzed all stomach contents (algae and zooplankton) on optical microscopy, quantified and identified each food item at the lowest possible taxonomic level using classic bibliography, for zooplankton (Vucetich, 1973; Reid, 1985; Matsumura-Tundisi, 1986; Velho \& Lansac-Tôha, 1996), and for algae (Prescott et al., 1981; Anagnostidis \& Komárek, 1985; LangeBertalot, 1995). Empty stomachs were discarded for further analysis (48 stomachs). In the data analysis, we used each fish stomach of each treatment, and empty stomachs were discarded. Thus, at the end of the experiment, 12 stomachs were analyzed in $\mathrm{T} 1$ and 15 in T2, and three aquariums as replicates to each treatment.

Algae from control microcosms were removed from the glass slides using a stainless-steel blade wrapped in aluminum foil and jets of distilled water (Algarte et al., 2014), and preserved in 0.5\% acetic acid Lugol's iodine solution for further quantification. The area colonized and scraped from the glass slides was determined to be included in the estimate of algal density (Utermöhl, 1958). Algae were quantified in random fields on an inverted Olympus CK2 microscope, until at least 100 individuals of the most common species (cells, 
colonies or filaments) of each sample were counted. The species identification was performed using classical literature, and the classification system used for algal classes was the proposed by Round (1965, 1971).

This experimental research was approved by the Instituto Chico Mendes de Conservação da Biodiversidade (SISBIO/ ICMBIO; License no 22442-1) and the Ethical Board for the use of experimental animals from the Universidade Estadual de Maringá (CEUA; Technical Advice $\left.n^{\circ} 123 / 2010\right)$. At the end of the experiment, the unused fish were returned alive to the natural environment.

\subsection{Data analysis}

The algal taxa of the stomach contents were classified according to life forms based on Steinman (1996), adapted by how the algae are attached to the substrate: (i) low-profile, prostrate algae and firmly adhered to the substrate (e.g. Cocconeis, Eunotia, Characium), (ii) medium-profile, pedunculated, loosely adhered, short filaments and pseudofilaments (e.g. Gomphonema, Nitzschia, Ulnaria, Achnanthidium and Desmidiaceae) and (iii) high-profile, erect filaments, loosely adhered filaments, pseudofilaments and their epiphytes (e.g. Oedogonium, Spirogyra, Spondylosium).

To test the first (fish consume zooplankton when available, therefore reducing algae consumption and increasing algal biomass) and third hypotheses (species from the low-profile of the periphytic algal matrix are less consumed) and assess if the abundance and richness of algae consumed were different between treatments (T1 and T2) and among periphytic-biofilm profiles (low, medium and high), we performed a Generalized Linear Mixed Model (GLMM). The response variables assumed a negative binomial distribution, due to overdispersion. Here, the aquarium (replicates) identity was controlled as random variable in the model, and was used 12 fish individuals in T1 and 15 fish individuals in T2. The significance of the deviance captured by the fixed variables was analyzed using a deviance analysis (Type II test).

To test the second hypothesis that fish consume the same algal species independently of the presence of zooplankton and to evaluate if the composition of algae consumed differed between treatments, we used a Principal Coordinates Analysis (PCoA), using abundance data and the Bray-Curtis dissimilarity coefficient (Legendre \& Legendre, 1998). To compare algal compositions between the control and the treatments, we did a PCoA using presence and absence data on algal species. The algae from the control were also classified according to life forms, and we carried out exploratory analyses to verify which life forms predominated in control.

For the network analysis, the interaction between resource categories and fish individuals was represented in a quantitative matrix for each treatment, where the rows, $i$, are the algal species and other food item categories, such as zooplankton, some debris, insects and fragments of insects (prey or resource), columns, $j$, are the fish individuals (predator or consumer), and $\mathrm{Yij}=$ number of interactions between resource categories $i$ and the fish individual j. A link between the two sets of nodes represents the feeding interaction between the individuals (in our study individuals of a fish species $M$. sanctaefilomenae) and the resource categories (algae species and other food items). The interactions represented the total quantity of food items (mainly algae) in the fish individuals' stomach contents. To test the fourth hypothesis and to investigate the differences in the individualresource network structure comparing the two treatments, we calculated the resource category degree and fish individual degree (K-number of lines on a node in a graph), the medium degree of the resource categories and fish individuals (K.M), nestedness, and modularity. Here, in the network analysis, algae and other food items with a high degree represent the resource consumed by a greater number of fish individuals in each treatment.

We assessed nestedness by computing the metric WNODF (Almeida-Neto \& Ulrich, 2011), which computes the weighted nested overlap and decreasing filling of quantitative matrices, ranging between 0 (non-nestedness) to 100 (perfect nestedness). We assessed modules using the QuaBiMo 22 algorithm, which computes modules in quantitative bipartite networks (Dormann \& Strauss, 2013). It ranges between 0 (random network with no modules) and 1 (maximum modularity). To calculate nestedness and modularity significance we used model 2 (Bascompte et al., 2003) as null model, which generates networks in which the probability of two species interacting depends on the number of interactions of both species in the real network.

To test the fifth hypothesis related to network diversity, we calculated specialization, interaction evenness and interaction diversity. The specialization degree $\left(H_{2}^{\prime}\right)$ is a network-level measure which 
describes the exclusiveness of interactions within the network considering the species degree (how connected a species is), and it ranges from 0 (all species interacting with the same partner, i.e. low specialization) to 1 (high specialization). Interaction evenness (IE) is an index that gives the uniformity of interactions in the networks (Blüthgen, 2010); that is, the homogeneity of interaction frequencies in all links in the network, ranging from 0 to 1 , where values close to one represent the uniformity of interaction between the species. Interaction diversity (ID) is a metric based on Shannon Entropy, and it is the quantitative analogue to the total number of links (Bersier et al., 2002).

We conducted all analyses in the $\mathrm{R}$ software (R Core Team, 2019) with the vegan (Oksanen et al., 2017), MASS (Venables \& Ripley, 2002), ape (Paradis \& Schliep, 2019), and ggplot2 (Wickham $\&$ Winston, 2016) packages. Network metrics were calculated using the Bipartite package (Dormann et al., 2008).

\section{Results}

The algae found in fish stomachs were represented by 149 species and six classes, Chlorophyceae, Bacillariophyceae, Zygnematophyceae, Cyanophyceae, Euglenophyceae and Rhodophycea (Figure 2). In T1 the highest abundance of algae was registered for Chlorophyceae $(1,460$ individuals, mean $=103.1, \mathrm{SD}=79.2)$, followed by Bacillariophyceae (1,200 individuals, mean $=85.3, \mathrm{SD}=58.2$ ) (Figure 2$).$ In $\mathrm{T} 2$ the pattern in abundance was similar, with highest abundance for Chlorophyceae (1,359 individuals, mean $=122.5, S D=203.5)$ followed by Bacillariophyceae $(1,019$ individuals, mean $=84.9$, $\mathrm{SD}=89.3$ ) (Figure 2).

The main food items found in both treatments were Ulnaria ulna (Nitzch) Compère, Achnanthidium minutissimum (Kützing) Czarnecki, Fragilaria sp.1, Synedra goulardii Brébisson ex Cleve \& Grunow and Oedogonium sp.1 (Figure 3). The species with the highest abundance in T1 were Ulnaria ulna $(\mathrm{n}=1124$, mean $=93.6$, $\mathrm{SD}=186.4)$; Achnanthidium minutissimum $(\mathrm{n}=417$, mean $=34.7, \mathrm{SD}=56.4)$ and Fragilaria sp. $1(n=162$, mean $=13.5, S D=22.7)($ Figure 3$)$, and in T2 were Ulnaria ulna ( $\mathrm{n}=988$, mean $=65.8$, $\mathrm{SD}=58.1)$, Achnanthidium minutissimum $(\mathrm{n}=599$, mean $=39.9, \mathrm{SD}=35.1)$ and Fragilaria sp. $1(\mathrm{n}=276$, mean $=18.4, \mathrm{SD}=18.8$ ) (Figure 3). We also found other contents in the fish stomachs, but much less frequently, such as zooplankton, some debris, insects and fragments of insects. From the total, Copepoda sp. 1 represented $0.33 \%$, Copepoda sp. $20.03 \%$, debris $1.67 \%$, insect fragments $0.15 \%$, zooplankton fragments $0.07 \%$ and insects $0.05 \%$. The zooplankton found in stomachs from T1 was possibly consumed in the acclimatization tanks prior to the experiment.

The GLMM results indicated that algae that occupy different positions in the periphytic biofilm were consumed in different abundances $\left(X^{2}=181.47 ; p<0.001\right)$. Species from the medium-profile were more consumed than that of the high and low profiles and there was also a difference in the consumption of algal high and low profiles (Figure 4a; Tables 1 and 2). However, algal abundance in the stomach contents did not differ
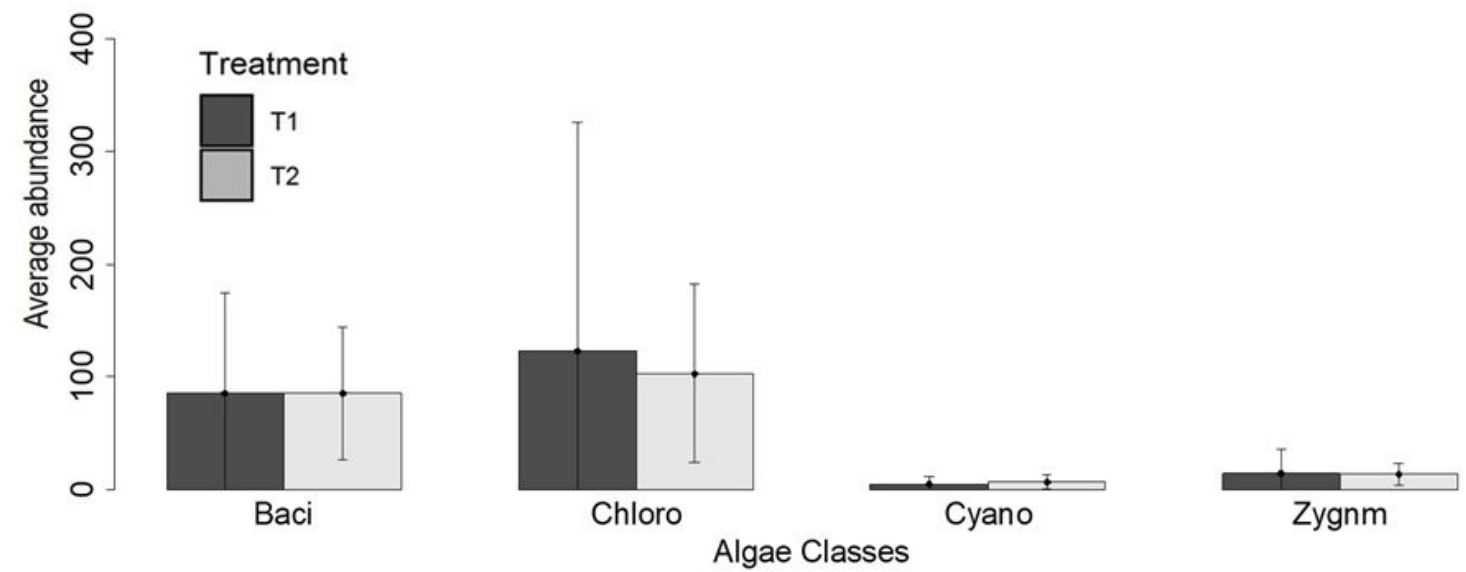

Figure 2. Abundance of the main periphytic algal classes recorded in the treatments (Baci - Bacillariophyceae; Chloro - Chlorophyceae; Cyano - Cyanophyceae; Zygnm - Zygnemaphyceae. T1 (without zooplankton) and T2 (with zooplankton). 


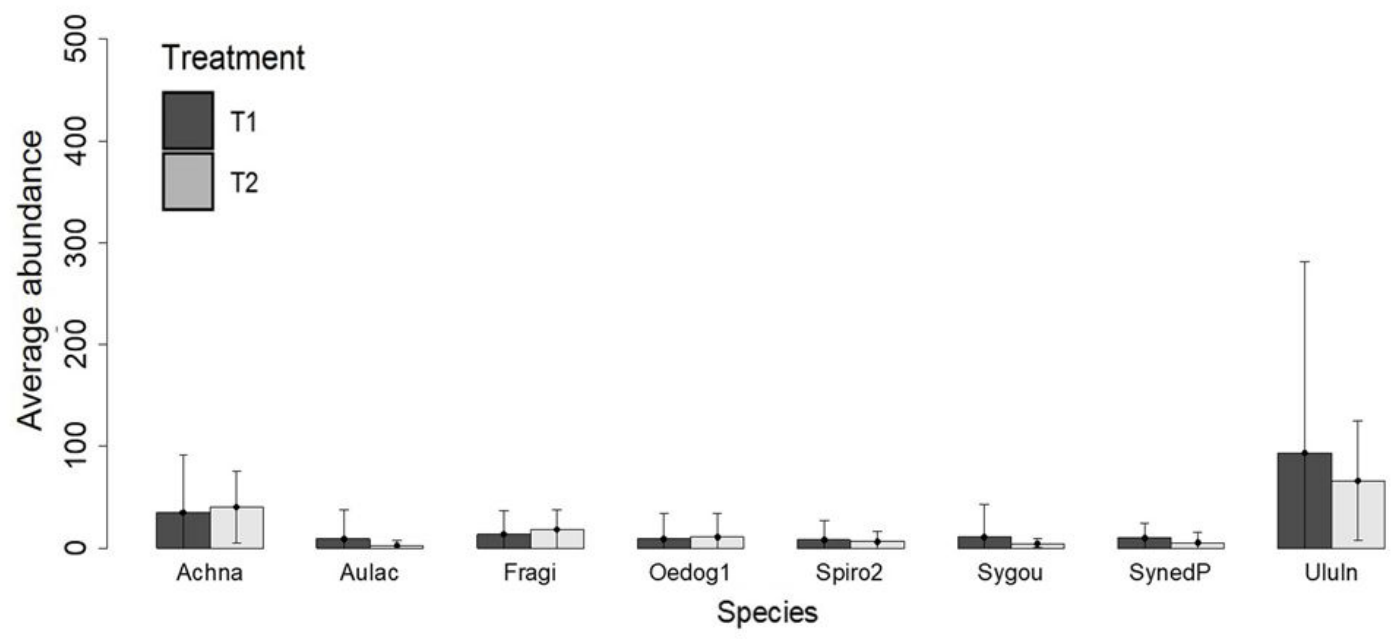

Figure 3. Abundance of periphytic algal species recorded in the treatments T1 (without zooplankton) and T2 (with zooplankton). Achna - Achnanthidium minutissimum; Aulac - Aulacoseira sp.1; Fragi - Fragilaria sp.1; Oedog1 Oedogonium sp.1; Spiro2 - Spirogyra sp.1; Sygou - Synedra goulardii; SynedP - Synedra sp.1; Ululn - Ulnaria ulna.
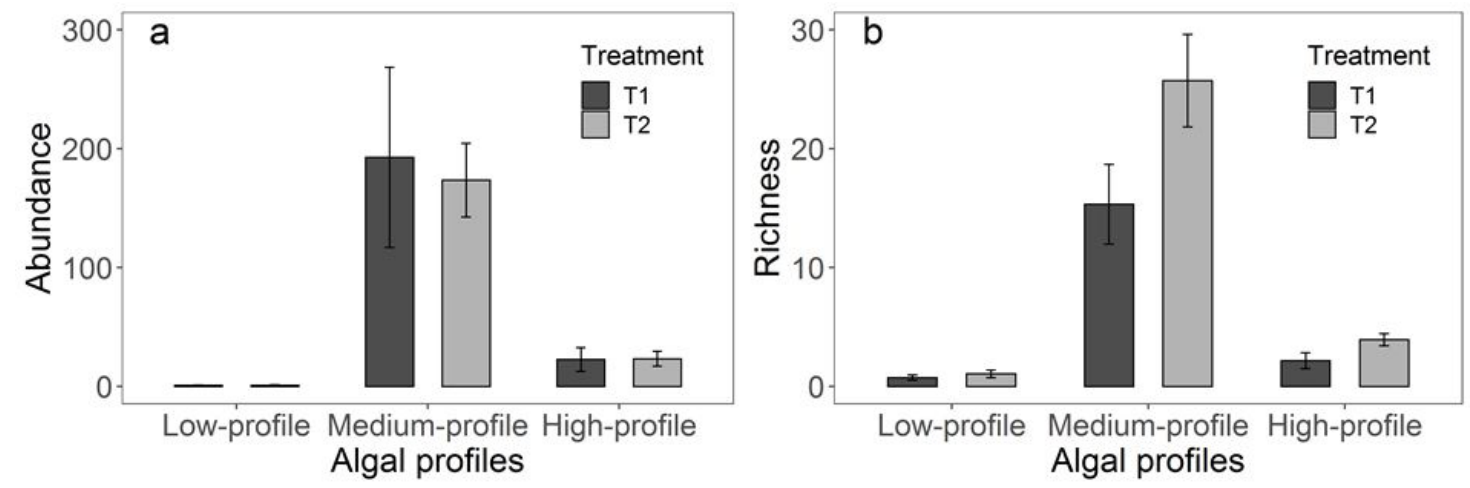

Figure 4. Mean and standard error of the abundance (a) and species richness (b) of periphytic algal profiles from the food content of Moenkhausia sanctaefilomenae at treatments T1 (without zooplankton) and T2 (with zooplankton).

Table 1. Analyses of deviance table (Type II) of fixed effects of treatments (without and with zooplankton) and periphytic algal profile (low, medium and high) on the abundance and richness of algae.

\begin{tabular}{cccc}
\hline & Treatment & Algal profile & Treatment * Algal profile \\
\hline Abundance & $X^{2}=0.003 ; p=0.96$ & $X^{2}=181.47 ; p<0.001^{*}$ & $X^{2}=0.059 ; p=0.097$ \\
Richness & $X^{2}=6.93 ; p=0.01^{*}$ & $X^{2}=161.61 ; p<0.001^{*}$ & $X^{2}=0.17 ; p=0.092$ \\
\hline
\end{tabular}

*indicate significant values $(\mathrm{p}<0.05)$.

Table 2. Results from generalized linear mixed model fit with binomial negative estimation of the abundance of periphytic algal profiles (low, medium and high) from the food content of Moenkhausia sanctaeflomenae between treatments T1 (without zooplankton) and T2 (with zooplankton). The intercept represents the levels "Treatment-T1" and "High-profile". SD- standard deviation. SE- standard error. Z- test parameter. P-probability. Residual SD- residual standard deviation.

\begin{tabular}{|c|c|c|c|c|}
\hline Random effects & SD & Residual SD & & \\
\hline Aquarium ID & $8.84 e-7$ & $7.8 e-13$ & & \\
\hline Fixed effects & Estimate & SE & $z$ & $P$ \\
\hline Intercept & 3.12 & 0.36 & 8.71 & $<0.001^{*}$ \\
\hline Treatment-T2 & 0.03 & 0.48 & 0.05 & 0.96 \\
\hline Low-profile & -3.12 & 0.58 & -5.38 & $<0.001^{*}$ \\
\hline Medium-profile & 2.14 & 0.50 & 4.24 & $<0.001^{*}$ \\
\hline Treatment-T2* Low-profile & 0.04 & 0.78 & 0.68 & 0.96 \\
\hline Treatment-T2* Medium-profile & -0.13 & 0.68 & & 0.85 \\
\hline
\end{tabular}

*indicate significant values $(\mathrm{p}<0.05)$ 
between treatments $\left(\chi^{2}=0.003 ; p=0.96\right)$, neither was there and interaction between algal profile and treatment $\left(\chi^{2}=0.059 ; \mathrm{p}=0.97\right)$.

Regarding the number of algal species consumed, there was a difference between treatments $\left(X^{2}=6.93\right.$; $\mathrm{p}=0.01)$ and profiles $\left(\chi^{2}=161.61 ; \mathrm{p}<0.001\right)$, but not for the interaction of factors $\left(\chi^{2}=0.17\right.$; $p=0.92)$. The consumption of different species of

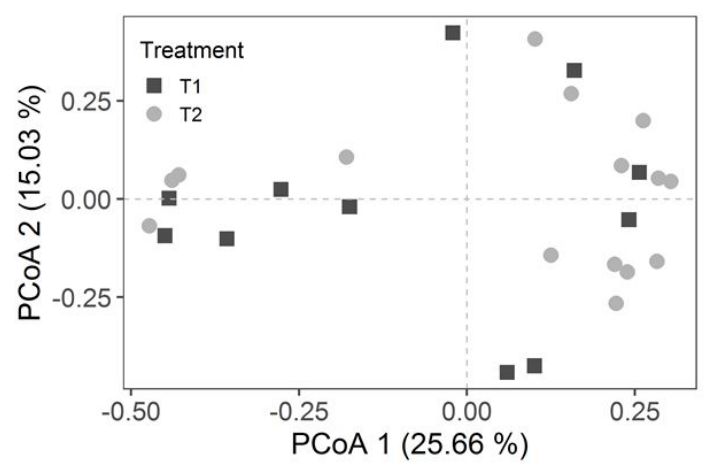

Figure 5. Ordination diagram of the Principal Coordinates Analysis (PCoA) based on the periphytic algal composition from the food content of Moenkhausia sanctaefilomenae between T1 (without zooplankton) and T2 (with zooplankton) treatments.

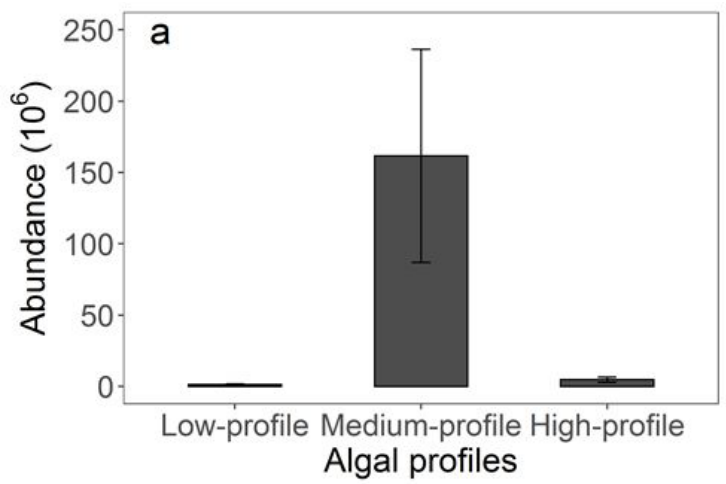

algae in T2 was greater than in T1. More species of the medium profile were consumed than of the high and low profiles and there was no difference in the number of algal species consumed from high and low profiles (Figure 4b; Tables 1 and 3).

The PCoA used to evaluate if the composition of algae consumed differed between the treatments, explained $41 \%$ of data variability. The results indicated that the composition of algal species (using abundance data) consumed between the treatments did not differ (Figure 5).

The analyses of the control aquarium showed that, on average, abundance and richness were higher for species of the medium profile (Figure 6). The PCoA used to compare the compositions between the control and the treatments explained $39.9 \%$ of data variability and indicated that algal species of the control differed from $\mathrm{T} 1$ and T2 (Figure 7).

The medium degree of resource categories and fish individuals differed between the treatments, where T2 presented the higher values (T1 - K.M resource: 2.3; K.M fish individuals: 19.2; T2 - K.M resource: 3.6; K.M fish individuals: 31.1). The algal

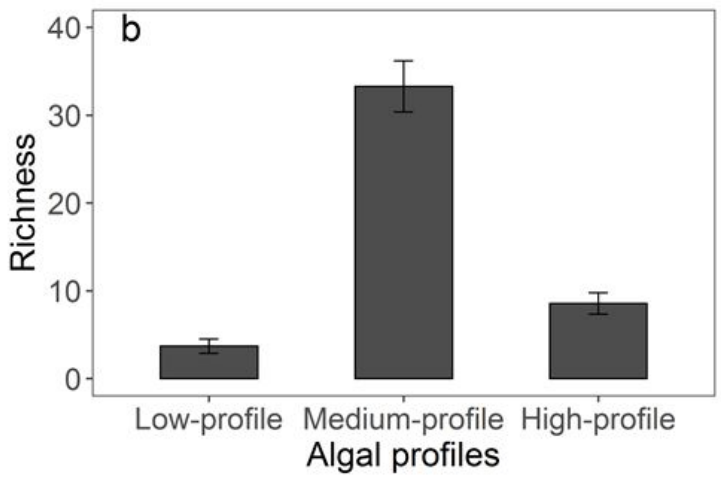

Figure 6. Mean and standard error of the abundance (a) and richness (b) of periphytic algal profiles from the control aquarium.

Table 3. Results from generalized linear mixed model fit with binomial negative estimation of the richness of periphytic algal profiles (low, medium and high) from the food content of Moenkhausia sanctaefilomenae between treatments T1 (without zooplankton) and T2 (with zooplankton). The intercept represents the levels "Treatment-T1" and "High-profile".

\begin{tabular}{|c|c|c|c|c|}
\hline Random effects & SD & Residual SD & & \\
\hline Aquarium ID & $3.93 e-7$ & $1.54 \mathrm{e}-13$ & & \\
\hline Fixed effects & Estimate & SE & $z$ & $P$ \\
\hline Intercept & 0.77 & 0.27 & 2.82 & $0.00^{*}$ \\
\hline Treatment-T2 & 0.60 & 0.35 & 1.71 & 0.08 \\
\hline Low-profile & -1.06 & 0.47 & -2.25 & $0.02^{*}$ \\
\hline Medium-profile & -1.96 & 0.34 & 5.73 & $<0.001^{*}$ \\
\hline Treatment-T2* Low-profile & -0.24 & 0.60 & -0.41 & 0.68 \\
\hline Treatment-T2* Medium-profile & -0.08 & 0.44 & -0.18 & 0.86 \\
\hline
\end{tabular}

*indicate significant values $(\mathrm{p}<0.05)$. 


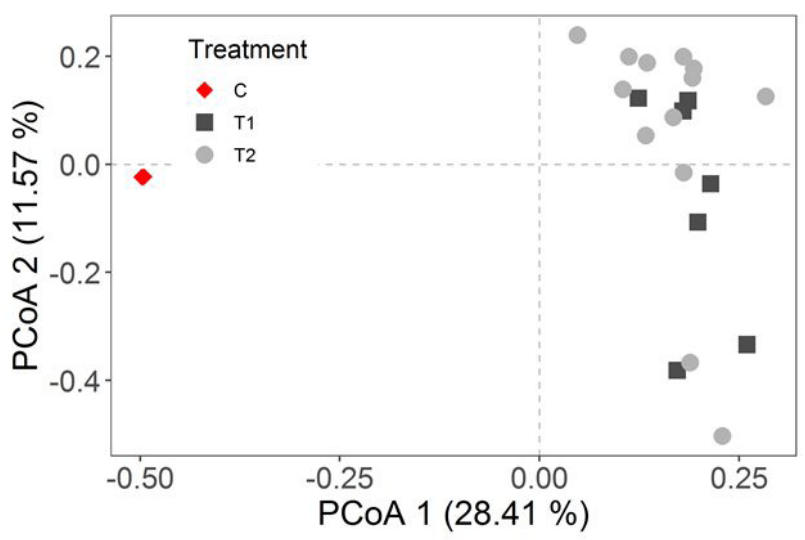

Figure 7. Ordination diagram of the Principal Coordinates Analysis (PCoA) based on the periphytic algal composition from the control and food content of Moenkhausia sanctaefilomenae between T1 (without zooplankton) and T2 (with zooplankton) treatments.

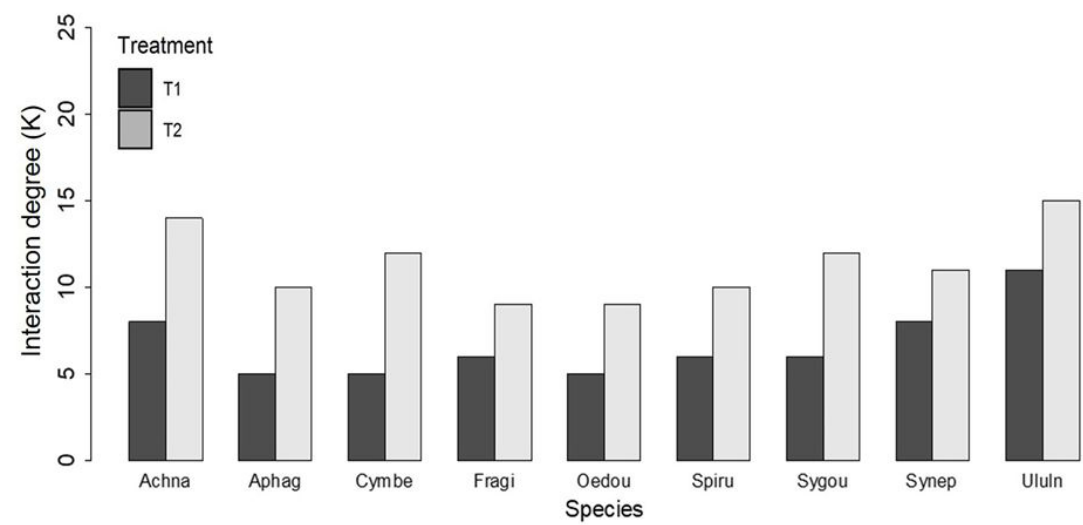

Figure 8. Interaction degree of periphytic algal species recorded in the treatment T1 (without zooplankton) and T2 (with zooplankton). Achna - Achnanthidium minutissimum; Aphag - Aphanocapsa sp.1; Cymbe - Cymbella sp.1; Fragi - Fragilaria sp.1; Oedou - Oedogonium sp.1; Spiru - Spirogyra sp.1; Sygou - Synedra goulardii; Synep - Synedra sp.1; Ululn - Ulnaria ulna.

species with the highest degree in the treatments are shown in Figure 8, where the majority belong to the medium profile (Ulnaria ulna and Achnanthidium minutissimum), and three species to the high profile (Spirogyra sp.1, Oedogonium sp.1 and Oedogonium sp.2). The species more consumed (Figure 3) and the species with the highest degree values (interactions, that is, consumed by a larger number of fish individuals in each treatment) (Figure 8), did not differ. In relation to the structure metrics of interaction network, the treatments differed only for nestedness. T1 was not significantly nested (WNODF $=14.7 ; \mathrm{p}=0.06$ ), while T2 was significantly nested $(\mathrm{WNODF}=18.7 ; \mathrm{p}=0.009)$. Both networks, $\mathrm{T} 1$ and T2, were modular $(\mathrm{T} 1 \mathrm{Mod}=0.41, \mathrm{p}<$ 0.005 ; T2 $\mathrm{Mod}=0.23, \mathrm{p}<0.005)$, rejecting our hypothesis.
The T1 network showed less interaction diversity and interaction evenness, while $\mathrm{T} 2$, rejecting part of our hypothesis, showed less specialization degree (T1: ID = 3; $\mathrm{EV}=0.49 ; \mathrm{H} 2{ }^{\prime}=0.46 ; \mathrm{T} 2: \mathrm{ID}=5$; $\mathrm{EV}=0.62 ; \mathrm{H} 2{ }^{\prime}=0.22$; Figure 9$)$. We also analyzed the data for all network metrics removing the food items other than algae, such as zooplankton, some debris, insects and fragments of insects. The results of removing these food items did not differ due to the great representativeness of algae in the feeding of M. sanctaefilomenae. In Figure 9, the fish individuals with higher degree were individuals that remained more days in the experiments (six days, see figure caption). We analyzed the data removing individuals that had spent less than 4 days in the experiment and the results also did not differ. 
T1

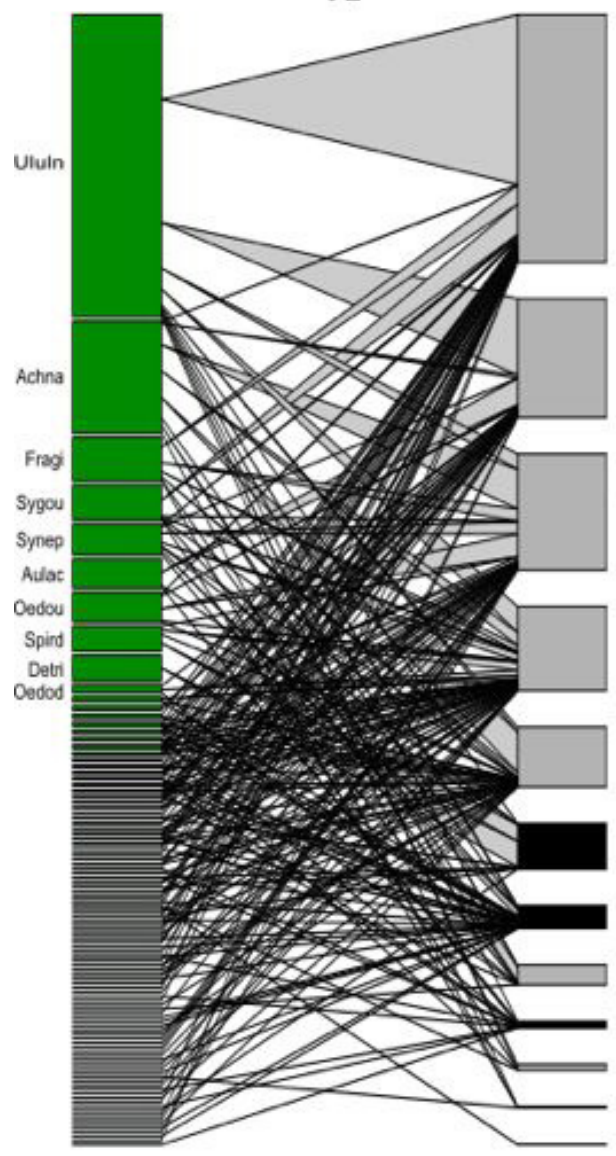

T2

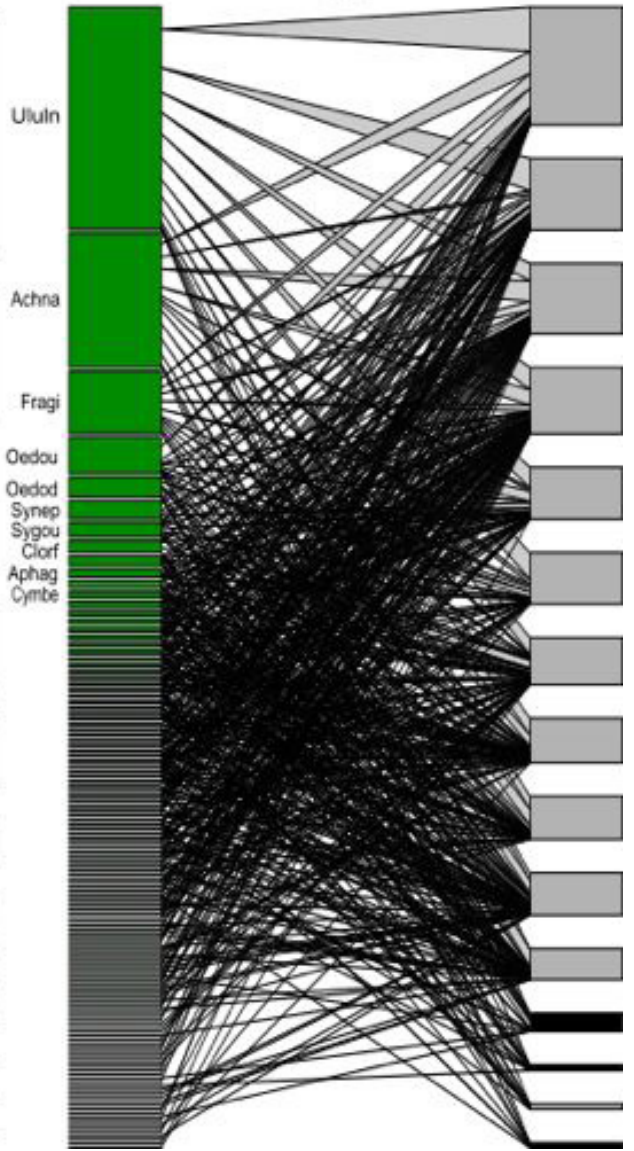

Figure 9. Interaction networks based on the resource categories (periphytic algae from the food content and other food items) (left on the graphs- green) of Moenkhausia sanctaefilomenae (right on the graphs- gray) in treatments T1 (without zooplankton) and T2 (with zooplankton). Gray lines represent the species interactions, and the thickness of the line indicates the interaction frequency (in these networks, the abundance of the food items in the stomach contents of $M$. sanctaefilomenae). The size of the bars represents the species or individual degree (number of species interactions). Black bars depict $M$. sanctaefilomenae individuals that had spent less than 4 days in the experiment. Food items labels: Ululn - Ulnaria ulna; Achna - Achnanthidium minutissimum; Fragi - Fragilaria sp.1; Sygou - Synedra goulardii; Synep - Synedra sp.1; Aulac - Aulacoseira sp.1; Oedou - Oedogonium sp.1; Spird - Spirogyra sp.2; DetriDebris; Oedod - Oedogonium sp.2; Clorf - Chlorophyceae sp.1; Aphag - Aphanocapsa sp.1; Cymbe - Cymbella sp.1.

\section{Discussion}

Our results of top-down cascading effects of fish on algal species demonstrated that the fish diet did not differ between food webs with presence or absence of zooplankton (intermediate herbivore), with algal composition being similar among them. The use of periphytic algae as a resource by M. sanctaefilomenae corroborates previous studies (Santos et al., 2009; Dias et al., 2017), and the consumption among profiles of the periphytic algal matrix was similar between treatments, with higher consumption of species from the medium profile, partially corroborating the hypothesis of this study. Algae belonging to the medium profile also predominated in the control, and therefore were the most consumed. However, the results of the interaction networks demonstrated that fish individuals differed in how they share resources in the presence or absence of zooplankton. The two treatments presented network modularity, but differed for nestedness, which refuted our hypotheses of no difference in the nestedness of the networks between treatments. The treatment with zooplankton was also different in terms of network diversity, with greater interaction evenness and diversity, but with less specialization of interactions, which partially refuted our hypothesis regarding specialization.

The presence of zooplankton in the diet of M. sanctaefilomenae, specifically Cladocera and 
Copepoda (Santana-Porto \& Andrian, 2009; Crippa et al., 2009; Carniatto et al. 2019) and different feeding habits according to the environment, are some of the indications of the species' ability to consume other resources when available in the environment. However, our results indicated a higher consumption of periphytic algae, even with the availability of zooplankton, reinforcing the feeding plasticity. M. sanctaefilomenae has a low degree of selectivity, changing its diet according to the most abundant resource in the environment (Dias et al., 2017). Thus, this evidence does not indicate a preference of the species for periphytic algae, but the ability to take advantage of a more abundant resource in the environment.

Considering $M$. sanctaefilomenae collector behavior of food resources in the water column (Casatti et al., 2002), it was expected that the species would consume the algae most exposed in the periphytic matrix, such as algae present in the medium and especially in the high profile, which would be more easily removed from the substrate (Steinman, 1996, Biggs et al., 1998). Our results demonstrated that $M$. sanctaeflomenae consumed the medium-profile algae in higher abundance, regardless of the presence of zooplankton. Due to the adherence of these algae to the matrix, they probably remained more prostrate to the artificial substrate, while the high-profile algae may have come off and remained loose in the water column. However, low-profile algae are much more adherent than medium-profile algae, which makes it difficult for fish to use this resource. Still, medium-profile algae were the more abundant group in the glass slides, which also favored the use of this resource by fish. The classification of algal medium profile from Steinman (1996) includes many types of adherence strategy, such as pedunculated, loosely adhered, short filaments, pseudofilaments, also including motile algae and planktonic algae. These varied traits favor the ability to survive under different environmental conditions (Jamoneau et al., 2018), and may justify the greater predominance of these groups in the composition of all treatments.

Studies have confirmed that herbivores and their distinct ways of feeding and foraging can change far beyond the structure of periphytic algal communities, changing composition and richness (Cattaneo \& Kalff, 1986; McCormick \& Stevenson, 1991), densities and even predominance of functional characteristics, life forms and species size (Nicola et al., 1990; Steinman et al., 1992; Hillebrand et al., 2000; Dunck et al., 2018). In our study, we demonstrated that the feeding habit of $M$. sanctaefilomenae altered the periphytic algal community of artificial substrates, since it consumed a higher proportion of medium-profile algae than low and high-profile species. In addition, it fed predominantly on Ulnaria ulna and Achnanthidium minutissimum in both treatments, species that make up the medium profile due to the ability to form pseudofilaments, peduncles and chains. Although studies indicate that this ability can difficult predation (Passy, 2007), M. sanctaefilomenae was possibly not harmed by this algal life habit. These diatoms (Ulnaria ulna and Achnanthidium minutissimum) were also the species with the highest degree of interaction with the fish. In the treatment with zooplankton, Ulnaria ulna was consumed by all individuals of $M$. sanctaefilomenae, and therefore Ulnaria ulna can be considered a generalist species in this predator-prey interaction.

The structure and stability of trophic interaction among species are highly dynamic, varying for different causes (Bolker et al., 2003), including for the presence or not of an intermediate consumer, which was observed in our short experiment. The detection of how consumers feed and how their trophic relationships affect community and ecosystems is a challenge, and analyses of complex networks may help to detect complementary patterns from those found using only the abundance and composition of the interacting species.

In our study, we used the metrics of complex networks to a population level, called individualresource networks, since in our experiment the predators were fish individuals of $M$. sanctaeflomenae that consumed mainly algal species and other food items, such as zooplankton, some debris, insects and fragments of insects. In the treatment with the presence of zooplankton, we can consider two perspectives regarding the zooplankton: as an algae intermediate consumer and also as an alternative resource to the fish individuals. For the perspective of being a consumer, the fish and zooplankton have distinct behavior and feeding modes, so it was expected that the presence of zooplankton would not affect the nested structure of the network, only the modularity and network diversity. Pires and coauthors (2011) investigated networks of 10 vertebrate species, including mouse opossum, lizard and frog species and they found that nested networks are more common than modular individual-resource networks. However, our results demonstrated that the networks in both treatments were modular, where individuals 
might be organized in distinct groups formed by individuals specialized in distinct sets of resources. Only the treatment with zooplankton was nested, suggesting that these populations are formed by both opportunistic and selective individuals. Consequently, the nested pattern may have resulted in less specialization for this network compared to the treatment without zooplankton. On the other hand, in the network with zooplankton, the fish individuals interacted with a greater number of algal species, which probably contributed to the increase in the interaction diversity and uniformity (evenness) of this network. Some studies also found a positive relationship between nestedness and high food resource availability (Araújo et al., 2010; Cantor et al., 2013). When we consider zooplankton as an alternative resource to the fish individuals, the treatment with the presence of zooplankton probably presented higher resource availability than the treatment without zooplankton, and individuals may have differed in selectivity, causing asymmetries and nestedness, although our results indicated a higher consumption of periphytic algae than zooplankton.

\section{Conclusion}

We demonstrated that when $M$. sanctaefilomenae is kept experimentally in aquariums with available food composed of zooplankton and periphytic algae, it fed predominantly on algae that make up the medium layers of the periphytic biofilm, which were the most abundant. This species of fish can take advantage of an abundant resource in the environment and the presence or absence of zooplankton does not alter this herbivory interaction. Regarding the individual-resource network patterns, individuals presented different diet preferences in the two treatments (modular networks), such as the difference in the generalist algal species (consumed by several individuals in each treatment), presence of opportunistic and selective fish individuals in the treatment with zooplankton (nested pattern) and in the distribution and diversity of interactions. To our knowledge, the individual-resource networks approach was not observed in studies developed in microcosm experiments with vertebrate species, only in lake experiments (Araújo et al., 2008). Future studies with individual-resource networks should be pursued, also investigating how morphological traits and sex influence the resource niche partition in microcosm experiments.

\section{Acknowledgements}

We thank the Conselho Nacional de Desenvolvimento Científico e Tecnológico (CNPq) and the Coordenação de Aperfeiçoamento de Pessoal de Nível Superior - Brasil (CAPES) for granting U.L. Fernandes and L. Palheta doctoral scholarships, respectively; the Biodiversity Research Consortium Brazil-Norway (BRC), HydroAlunorte, for granting G. Casas post-doctoral scholarships (\#12/16 Ecological Interaction Project); the CNPq for granting T.M. Lopes postdoctoral scholarships and L. Rodrigues productivity support; to CAPES for granting B. Dunck postdoctoral scholarships; the Long-Term Ecological Research (CNPq-PELD-Brazil) and the Núcleo de Pesquisa em Limnologia, Ictiologia e Aquicultura (Nupélia) for technical and logistical support during the conduction of this study. We also thank Maria Gabriela Junqueira, Diogo Castanho Amaral, the Laboratory of Zooplankton (UEM) and Ecology of Fish (UEM) for scientific support.

\section{References}

ALANIS, J.G., SARMA, S.S.S. and NANDINI, S. Prey selectivity and functional response by larval red-eyed tetra Moenkhausia sanctaefilomenae (Steindachner, 1907) (Characiformes: Characidae). Brazilian Archives of Biology and Technology, 2009, 52(5), 1209-1216. http://dx.doi.org/10.1590/S151689132009000500019

ALGARTE, V.M., RODRIGUES, L., LANDEIRO, V.L., SIQUEIRA, T. and BINI, L.M. Variance partitioning of deconstructed periphyton communities: does the use of biological traits matter? Hydrobiologia, 2014, 722(1), 279-290. http://dx.doi.org/10.1007/s10750013-1711-6.

ALMEIDA-NETO, M. and ULRICH, W. A straightforward computational approach for measuring nestedness using quantitative matrices. Environmental Modelling \& Software, 2011, 26(2), 173-178. http://dx.doi.org/10.1016/j. envsoft.2010.08.003.

ANAGNOSTIDIS, K. and KOMÁREK, J. Modern approach to the classification of Cyanophytes. 1- Introduction. Archiv für Hydrobiologie, 1985, 71(1-2), 291-302.

ARAÚJO, M.S. and GUIMARÃES JÚNIOR, P.R., SVANBÄCK, R., PINHEIRO, A., GUIMARÁES, P., REIS, S.F. and BOLNICK, D.I. Network analysis reveals contrasting effects of intraspecific competition on individual vs. population diets. Ecology, 2008, 89(7), 1981-1993. http://dx.doi.org/10.1890/070630.1. PMid:18705384. 
ARAÚJO, M.S., MARTINS, E.G., CRUZ, L.D., FERNANDES, F.R., LINHARES, A.X., REIS, S.F. and GUIMARÁES JÚNIOR, P.R. Nested diets: a novel pattern of individual冈level resource use. Oikos, 2010, 119(1), 81-88. http://dx.doi.org/10.1111/ j.1600-0706.2009.17624.x.

BASCOMPTE, J., JORDANO, P., MELIÁN, C.J. and OLESEN, J.M. The nested assembly of plantanimal mutualistic networks. Proceedings of the National Academy of Sciences of the United States of America, 2003, 100(16), 9383-9387. http://dx.doi. org/10.1073/pnas.1633576100. PMid:12881488.

BERSIER, L.F., BANASEK-RICHTER, C. and CATTIN, M.F. Quantitative descriptors of food-web matrices. Ecology, 2002, 83(9), 2394-2407. http://dx.doi. org/10.1890/0012-9658(2002)083[2394:QDOF WM]2.0.CO;2.

BIGGS, J.F., STEVENSON, R.J. and LOWE, R.L. A habitat matrix conceptual model for stream periphyton. Archiv für Hydrobiologie, 1998, 143(1), 21-56. http://dx.doi.org/10.1127/archivhydrobiol/143/1998/21.

BLÜTHGEN, N. Why network analysis is often disconnected from community ecology: a critique and an ecologist's guide. Basic and Applied Ecology, 2010, 11(3), 185-195. http://dx.doi.org/10.1016/j. baae.2010.01.001.

BOLKER, B.M., HOLYOAK, V., KŘIVAN, V., ROWE, L. and SCHMITZ, O. Connecting theoretical and empirical studies of trait冈mediated interactions. Ecology, 2003, 84(5), 1101-1114. http://dx.doi. org/10.1890/0012-9658(2003)084[1101:CTAES $\mathrm{O}] 2.0 . \mathrm{CO} ; 2$.

BOLNICK, D.I., YANG, L.H., FORDYCE, J.A., DAVIS, J.M. and SVANBÄCK, R. Measuring individual|llevel resource specialization. Ecology, 2002, 83(10), 2936-2941. http://dx.doi.org/10.1890/00129658(2002)083[2936:MILRS]2.0.CO;2.

BOTTRELL, H.H., DUNCAN, A., GLIWICZ, Z.M., GRYGIEREK, E., HERZIG, A., HILLBRICHTILKOWSKA, A., KURASAWA, H., LARSSON, P. and WEGLENSKA, T.A. Review of some problems in zooplankton production studies. Norwegian Journal of Zoology, 1976, 24, 419-456.

CAMARGO, N.F., OLIVEIRA, H.F.M., RIBEIRO, J.F., CAMARGO, A.J. and VIEIRA, E.M. A and VIEIRA, E.M. Availability of food resources and habitat structure shape the individual $\bigotimes$ resource network of a Neotropical marsupial. Ecology and Evolution, 2019, 9(7), 3946-3957. http://dx.doi.org/10.1002/ ece3.5024. PMid:31015979.

CANTOR, M., PIRES, M.M., LONGO, G.O., GUIMARÃES JÚNIOR, P.R. and SETZ, E.Z.F. Individual variation in resource use by opossums leading to nested fruit consumption. Oikos, 2013, 122(7), 1085-1093. http://dx.doi.org/10.1111/ j.1600-0706.2012.00070.x.
CARNIATTO, N., FUGI, R., QUIRINO, B.A., CUNHA, E.R. and THOMAZ, S.M. An invasive and a native macrophyte species provide similar feeding habitat for fish. Ecology Freshwater Fish, 2019, 29(1), 112-120. http://dx.doi.org/10.1111/ eff.12499.

CASATTI, L. Alimentação dos peixes em um riacho do parque estadual Morro do Diabo, bacia do alto rio Paraná, sudeste do Brasil. Biota Neotropica, 2002, 2(2), 1-14. http://dx.doi.org/10.1590/S167606032002000200012 .

CASATTI, L., LANGEANI, F. and CASTRO, R.M.C. Peixes de riacho do Parque Estadual Morro do Diabo, Bacia do alto rio Paraná. Biota Neotropica, 2002, 1(1), 1-15.

CATTANEO, A. and KALFF, J. The effect of grazer size manipulation on periphyton communities. Oecologia, 1986, 69(4), 612-617. http://dx.doi.org/10.1007/ BF00410371. PMid:28311624.

CONNELLY, S., PRINGLE, C.M., BARNUM, T., HUNTE-BROWN, M., KILHAM, S., WHILES, M.R., LIPS, K.R., COLÓN-GAUD, C. and BRENES, R. Initial versus longer-term effects of tadpole declines on algae in a Neotropical stream. Freshwater Biology, 2014, 59(6), 1113-1122. http:// dx.doi.org/10.1111/fwb.12326.

CRAWLEY, M.J. The relative importance of vertebrate and invertebrate herbivores in plant population dynamics. In: E.A. BERNAYS, ed. Insect-plant interactions. Boca Raton: CRC Press, 1989, pp. 45-71.

CRIPPA, V.E.L., HAHN, N.S. and FUGI, R. Food resource used by small-sized fish in macrophyte patches in ponds of the upper Paraná river floodplain. Acta Scientiarum. Biological Sciences, 2009, 31(2), 119-125.

DIAS, R.M., ORTEGA, J.C.G., GOMES, L.C. and AGOSTINHO, A.A. Trophic relationships in fish assemblages of neotropical floodplain lakes: selectivity and feeding overlap mediated by food availability. Iheringia. Série Zoologia, 2017, 107(0), e2017035. http://dx.doi.org/10.1590/1678-4766e2017035.

DIBBLE, E.D. and PELICICE, F.M. Influence of aquatic plant-specific habitat on an assemblage of small neotropical floodplain fishes. Ecology Freshwater Fish, 2010, 19(3), 381-389. http://dx.doi.org/10.1111/ j.1600-0633.2010.00420.x.

DORMANN, C. and STRAUSS, R. A method for detecting modules in quantitative bipartite networks. Methods in Ecology and Evolution, 2013, 5(1), 90-98. http://dx.doi.org/10.1111/2041-210X.12139.

DORMANN, C.F., GRUBER, B. and FRUND, J. The bipartite package version, 0.73 . Leipzig: $\mathrm{R}$ Project for Statistical Computing, 2008.

DUFFY, J.E. Biodiversity and ecosystem function: the consumer connection. Oikos, 2002, 99(2), 
201-219. http://dx.doi.org/10.1034/j.16000706.2002.990201.x.

DUNCK, B., AMARAL, D.C., FERNANDES, U.L., SANTANA, N.F., LOPES, T.M. and RODRIGUES, L. Herbivory effects on the periphytic algal functional diversity in lake ecosystems: an experimental approach. Hydrobiologia, 2018, 816(1), 231-241. http://dx.doi.org/10.1007/s10750-018-3587-y.

FEMINELLA, J.W. and HAWKINS, C.P. Interactions between stream herbivores and periphyton: a quantitative analysis of past experiments. Journal of the North American Benthological Society, 1995, 14(4), 465-509. http://dx.doi.org/10.2307/1467536.

HILLEBRAND, $\mathrm{H}$. and CARDINALE, B. Consumer effects decline with prey diversity. Ecology Letters, 2004, 7(3), 192-201. http://dx.doi.org/10.1111/ j.1461-0248.2004.00570.x.

HILLEBRAND, H. Meta-analysis of grazer control of periphyton biomass across aquatic ecosystems. Journal of Phycology, 2009, 45(4), 798-806. http:// dx.doi.org/10.1111/j.1529-8817.2009.00702.x. PMid:27034208.

HILLEBRAND, H., WORM, B. and LOTZE, H.K. Marine microbenthic community structure regulated by nitrogen loading and grazing pressure. Marine Ecology Progress Series, 2000, 204, 27-38. http:// dx.doi.org/10.3354/meps204027.

HUNTLY, N. Herbivores and the dynamics of communities and ecosystems. Annual Review of Ecology and Systematics, 1991, 22(1), 477-503. http:// dx.doi.org/10.1146/annurev.es.22.110191.002401.

JAMONEAU, A., PASSY, S.I., SOININEN, J., LEBOUCHER, T. and TISON-ROSEBERY, J. Beta diversity of diatom species and ecological guilds: Response to environmental and spatial mechanisms along the stream watercourse. Freshwater Biology, 2018, 63(1), 1-12. http://dx.doi.org/10.1111/ fwb. 12980 .

KUPFERBERG, S. Facilitation of periphyton production by tadpole grazing: functional differences between species. Freshwater Biology, 1997, 37(2), 427-439. http://dx.doi.org/10.1046/j.13652427.1997.00170.x.

LAMBERTI, G.A., ASHKENAS, L.R., GREGORY, S.V. and STEINMAN, A.D. Effects of three herbivores on periphyton communities in laboratory streams. Journal of the North American Benthological Society, 1987, 6(2), 92-104. http://dx.doi. org/10.2307/1467219.

LANGE-BERTALOT, H. Die diatomeen (Bacillariophyceae) em Ehrenberg's Material von Cayenne, Guyana Gallica (1843) von Erwin Reichardt. Iconographia Diatomologica Koenigstein: Koeltz Scientific Books, 1995, 107 p.

LEGENDRE, P. and LEGENDRE, L. Numerical ecology. Amsterdam: Elsevier, 1998.
LEWINSOHN, T.M., PRADO, P.I., JORDANO, P., BASCOMPTE, J. and OLESEN, J.M. Structure in plant-animal interaction assemblages. Oikos, 2006a, 113(1), 174-184. http://dx.doi.org/10.1111/j.00301299.2006.14583.x.

LEWINSOHN, T.W., LOYOLA, R.D. and PRADO, P.I. Matrizes, redes e ordenaçôes: a detecção de estrutura em comunidades interativas. Oecologia Brasiliensis, 2006b, 10(01), 90-104. http://dx.doi.org/10.4257/ oeco.2006.1001.06.

LIESS, A. and HILLEBRAND, H. Direct and indirect effects in herbivore - periphyton interactions. Archiv für Hydrobiologie, 2004, 159(4), 433-453. http:// dx.doi.org/10.1127/0003-9136/2004/0159-0433.

LOMAN, J. Effects of tadpole grazing on periphytic algae in ponds. Wetlands Ecology and Management, 2001, 9(2), 135-139. http://dx.doi. org/10.1023/A:1011106417883.

MATSUMURA-TUNDISI, T. Latitudinal distribution of Calanoida copepods in freshwater aquatic systems of Brazil. Brazilian Journal of Biology = Revista Brasileira de Biologia, 1986, 46, 527-553.

MCCORMICK, P.V. and STEVENSON, R.J. Grazer control of nutrient availability in the periphyton. Oecologia, 1991, 86(2), 287-291. http://dx.doi. org/10.1007/BF00317542. PMid:28313212.

MOULTON, T.P. Why the world is green, the waters are blue and food webs in small streams in the Atlantic Rainforest are predominantly driven by microalgae? Oecologia Brasiliensis, 2006, 10(1), 78-89. http:// dx.doi.org/10.4257/oeco.2006.1001.05.

NEURY-ORMANNI, J., VEDRENNE, J. and MORIN, $S$. Who eats who in biofilms? Exploring the drivers of microalgal and micro-meiofaunal abundance. Botany Letters, 2016, 163(2), 83-92. http://dx.doi.org/10.1 080/23818107.2016.1151827.

NICOLA, D.M., MCINTIRE, C.D., LAMBERTI, G.A., GREGORY, S. and ASHKENAS, L.R. Temporal patterns of grazer-periphyton interactions in laboratory streams. Freshwater Biology, 1990, 23(3), 475-489. http://dx.doi. org/10.1111/j.1365-2427.1990.tb00289.x.

OKSANEN, J., BLANCHET, R.F.G., KINDT, P., LEGENDRE, P.R., MINCHIN, R.B., O'HARA, G.L., SIMPSON, M., SOLYMOS, H.P., STEVENS, H. and WAGNER, H. Vegan: Community ecology package. $R$ package version [online]. Vienna: $\mathrm{R}$ Foundation for Statistical Computing, 2017 [viewed 11 Apr. 2020]. Available from: https://cran.r-project. org $/$ package $=$ vegan

PARADIS, E. and SCHLIEP, K. ape 5.0: an environment for modern phylogenetics and evolutionary analyses in R. Bioinformatics, 2019, 35(3), 526-528. http://dx.doi.org/10.1093/bioinformatics/bty633. PMid:30016406. 
PASSY, S.I. Diatom ecological guilds display distinct and predictable behavior along nutrient and disturbance gradients in running Waters. Aquatic Botany, 2007, 86(2), 171-178. http://dx.doi.org/10.1016/j. aquabot.2006.09.018.

PIRES, M.M., GUIMARÃES JÚNIOR, P.R., ARAÚJO, M.S., GIARETTA, A.A., COSTA, J.C.L. and REIS, S.F. The nested assembly of individual $\mathbb{}$ resource networks. Journal of Animal Ecology, 2011, 80(4), 896-903. http://dx.doi.org/10.1111/j.13652656.2011.01818.x. PMid:21644976.

POWER, M.E., STEWART, A.J. and MATTHEWS, W.J. Grazer control of attached algae in an Ozark Mountain stream: effects of short-term exclusion. Ecology, 1988, 69(6), 1894-1989. http://dx.doi. org/10.2307/1941166.

PRESCOTT, G.W., CROASDALE, H.T., VINIARD, W.C. and BICUDO, C.E.M. A synopsis of north american desmids: Parte II Desmidiaceae: Placodermae. Section 3. Linconl: University Nebraska Press, 1981.

R CORE TEAM. R: a language and environment for statistical computing [online]. Vienna: R Foundation for Statistical Computing, 2019 [viewed 11 Apr. 2020]. Available from: https:// www.R-project.org

REID, J. Chave de identificação e lista de referências bibliográficas para as espécies continentais sulamericanas de vida livre da ordem Cyclopoida (Crustacea, Copepoda). Boletim de Zoologia, 1985, 9(9), 17-143. http://dx.doi.org/10.11606/issn.25263358.bolzoo.1985.122293.

RODRIGUES, L. and BICUDO, D.C. Similarity among periphyton algal communities in a lentic-lotic gradient of the upper Paraná river floodplain, Brazil. Brazilian Journal of Botany, 2001, 24(3), 235-248. http:// dx.doi.org/10.1590/S0100-84042001000300001.

ROUND, F.E. The biology of the algae. London: Edward Arnold, 1965.

ROUND, F.E. The taxonomy of the Chlorophyta, 2. British Journal of Psychology, 1971, 6(2), 235-264.

SANTAMARÍA, S., ENOKSEN, C.A., OLESEN, J.M., TAVECCHIA, G., ROTGER, A., IGUAL, J.M. and TRAVESET, A. Diet composition of the lizard Podarcis lilfordi (Lacertidae) on 2 small islands: an individual-resource network approach. Current Zoology, 2020, 66(1), 39-49. http://dx.doi. org/10.1093/cz/zoz028. PMid:32467703.

SANTANA-PORTO, E.A. and ANDRIAN, I.F. Trophic organization the ichthyofauna of two semi-lentic environments in a floodplain on the upper Paraná river, Brazil. Acta Limnologica Brasiliensia, 2009, 21(3), 359-366.

SANTOS, C., SANTOS, I.A.L. and SILVA, C.J. Ecologia trófica de peixes ocorrentes em bancos de macrófitas aquáticas na bacia Caiçara, Pantanal Mato-Grossense. Revista Brasileira de Biociências, 2009, 7(4), 473-476.
SCHMITZ, O.J. Herbivory from individuals to ecosystems. Annual Review of Ecology Evolution and Systematics, 2008, 39(1), 133-152. http://dx.doi. org/10.1146/annurev.ecolsys.39.110707.173418.

SILVA, M.R. and HAHN, N.S. Influência da dieta sobre a abundância de Moenkhausia dichroura (Characiformes, Characidae) no reservatório de Manso, Estado de Mato Grosso. Iheringia. Série Zoologia, 2009, 99(3), 324-328. http://dx.doi. org/10.1590/S0073-47212009000300016.

STEINMAN, A.D. Effects of grazers on freshwater benthic algae. In: R.J. STEVENSON, M.L. BOTHWELL and R.L. LOWE, eds. Algal ecology. San Diego: Academic Press, 1996, pp. 341-373. http://dx.doi.org/10.1016/B978-0126684506/50041-2.

STEINMAN, A.D., MULHOLLAND, P.J. and HILL, W.R. Functional responses associated with growth form in stream algae. Journal of the North American Benthological Society, 1992, 11(2), 229-243. http:// dx.doi.org/10.2307/1467388.

STROGATZ, S.H. Exploring complex networks. Nature, 2001, 6825(410), 268-276. http://dx.doi. org/10.1038/35065725. PMid:11258382.

THOMPSON, R.M., BROSE, U., DUNNE, J.A., HALL JUNIOR, R.O., HLADYZ, S., KITCHING, R.L., MARTINEZ, N.D., RANTALA, H., ROMANUK, T.N., STOUFFER, D.B. and TYLIANAKIS, J.M. Food webs: reconciling the structure and function of biodiversity. Trends in Ecology \& Evolution, 2012, 27(12), 689-697. http://dx.doi.org/10.1016/j. tree.2012.08.005. PMid:22959162.

TINKER, T.M. and GUIMARÁES JÚNIOR, P.R. NOVAK, M., MARQUITTI, F.M., BODKIN, J.L., STAEDLER, M., BENTALL, G. and ESTES, J.A. Structure and mechanism of diet specialisation: testing models of individual variation in resource use with sea otters. Ecology Letters, 2012, 15(5), 475-483. http:// dx.doi.org/10.1111/j.1461-0248.2012.01760.x. PMid:22414160.

TÓFOLI, R.M., HAHN, N.S., ALVES, G.H.Z. and NOVAKOWSKI, G.C. Uso do alimento por duas espécies simpátricas de Moenkhausia (characiformes, Characidade) em um riacho da Regiāo CentroOeste do Brasil. Iheringia. Série Zoologia, 2010, 100(3), 201-206. http://dx.doi.org/10.1590/S007347212010000300003.

UTERMÖHL, H. Zur Vervollkommnung der quantitativen phytoplankton-methodic. Mitteilungen Internationale Vereinigung für Theoretische und Angewandte Limnologie, 1958, 9, 1-39.

VELHO, L.F.M. and LANSAC-TÔHA, F.A. Testate amoebae (Rhizopodea-Sarcodina) from zooplankton of the high Paraná river floodplain, state of Mato Grosso do Sul, Brazil: II. Family Difflugidae. Studies on Neotropical Fauna and Environment, 1996, 31(3-4), 174-192. http://dx.doi.org/10.1076/snfe.31.3.179.13342. 
VENABLES, W.N. and RIPLEY, B.D. Modern applied statistics with S. 4th ed. New York: Springer, 2002. http://dx.doi.org/10.1007/978-0-387-21706-2.

VUCETICH, M.C. Estudio de tecamebianos argentinos, en especial los del dominio pampasico. Revista del Museo de La Plata, 1973, 118, 287-322.

WICKHAM, H. and WINSTON, C. Ggplot2: an implementation of the grammar of graphics [online]. Vienna: R Foundation for Statistical Computing, 2016 [viewed 11 Apr. 2020]. Available from: https:// CRAN.R-project.org/package $=$ ggplot 2
YANG, G. and DUDGEON, D. Response of grazing impacts of an algivorous fish (Pseudogastromyzon myersi: Balitoridae) to seasonal disturbance in Hong Kong streams. Freshwater Biology, 2010, 55(2), 411-423. http://dx.doi.org/10.1111/j.13652427.2009.02290.x.

Received: 11 April 2020 Accepted: 07 October 2020

Associate Editor: Fabiana Schneck. 